\title{
Sosialisasi Konservasi Kura-Kura Kaki Gajah (Manouria Emys) di Kabupaten Kutai Kartanegara Provinsi Kalimantan Timur
}

\author{
Lutfi Maulana Hakim \\ Universitas Muhammadiyah Kalimantan Timur \\ lmh927@umkt.ac.id \\ Andri Tria Raharja \\ Universitas Muhammadiyah Kalimantan Timur \\ atr105@umkt.ac.id
}

\begin{abstract}
Abstrak
Sosialisasi konservasi kura-kura kaki gajah (manouria emys) di Kabupaten Kutai Kartanegara Provinsi Kalimantan Timur bertujuan: untuk memberikan sosialisasi kepada masyarakat yang berada di kawasan habitat kura-kura kaki gajah (manouria emys) untuk ikut dalam melakukan konservasi terhadap satwa dilindungi tersebut dengan melakukan pengembangbiakan atau penangkaran sebagai jalan alternatif konservasi yang dibenarkan oleh Balai konservasi Nasional. Menciptakan kondisi ekosistem alam yang baik sebagai habitat kura-kura dari segala bentuk pengrusakan. Ikut menjaga populasi kura-kura kaki gajah yang berada di alam liar dengan mengurangi penangkapan liar hewan eksotis tersebut. Melalui sosialisasi ini diharapkan bisa meminimalisir penangkapan kura-kura kaki gajah di alam liar dan memberikan edukasi kepada masyarakat yang menangkarkan satwa tersebut untuk mengambil langkah alternatif penangkaran yaitu dalam bentuk konservasi pelestarian kura-kura kaki gajah. Melalui pengabdian ini diharapkan mampu mengurangi kegiatan pengerusakan hutan sebagai habitat utama dari kura-kura kaki gajah. Pelaksanaan program sosialisasi konservasi ini telah dirancang dalam beberapa metode yang akan dilakukan selama proses awal sosialisasi dan selama kegiatan pengabdian ini berlangsung. Bentuk sosialisasi awal pengabdian ini dilaksanakan dengan mengundang penangkar dari masyarakat Desa Loa Kulu Kota untuk mensosialisasikan kegiatan yang akan dilangsungkan. Pada tahap awal sosialisasi target tim pengabdian adalah adanya komunikasi timbal balik tentang bagaimana cara yang efektif untuk mengajak penangkar kura-kura kaki gajah ikut berpartisipasi aktif dalam konservasi yang dilakukan oleh Bapak Kautsar Eka Wardhana dan Bapak Whendhy Bakti yang tinggal di Desa Loa Kulu Kota dan Anggana yang berpartisipasi dalam kegiatan ini. Hasil dari pelaksanaan kegiatan pengabdian ini adalah dapat menjadi pendorong kesadaran penangkar serta masyarakat untuk menjaga ekosistem hutan yang menjadi habitat kura-kura kaki gajah. Menumbuhkan kesadaran akan pentingnya perlindungan satwa endemik kalimantan agar tidak mengalami kepunahan serta meningkatkan ilmu pengetahuan, wawasan, pandangan yang luas tentang satwa endemik kalimantan dan cara konservasi kura-kura kaki gajah kepada masyarakat Kalimantan Timur.
\end{abstract}

Kata Kunci: Sosialisasi, konservasi, kura-kura. 


\section{Jurnal Abdimas Mahakam}

https://journal.uwgm.ac.id/index.php/abdimasmahakam

Online ISSN : 2549-5755

Juni 2018, Vol.2 No. 2

\section{Pendahuluan}

Kabupaten Kutai Kartanegara merupakan daerah yang kaya akan sumber daya alam terutama minyak bumi dan gas alam (migas) serta batubara sehingga perekonomian Kutai Kartanegara masih didominasi pertambangan dan penggalian. Daerah Kabupaten Kutai Kartanegara dibagi dalam 18 wilayah kecamatan dan 225 desa/kelurahan. Salah satu kecamatannya adalah kecamatan Loa Kulu yang terletak di tengah dari wilayah Kabupaten Kutai Kartanegara dan lebih dekat dengan wilayah Kota Tenggarong dan Kabupaten Kutai Kartanegara. Potensi sumber daya alam yang terdapat di Kecamatan Loa Kulu adalah pertanian, perkebunan, penangkaran, perikanan, pertambangan dan migas.

Kecamatan Loa Kulu memiliki luas wilayah mencapai 1. 405,7 km². Secara administratif, Kecamatan Loa Kulu terbagi menjadi 12 desa, yakni Desa Jembayan, Jembayan Dalam, Jembayan Tengah, Jonggon, Jonggon Jaya, Jongkang, Loa Kulu Kota, Loh Sumber, Lung Anai, Margahayu, Ponoragan, Rempanga, Sepakat, Sumber Sari dan Sungai Payang. Selain itu, Kecamatan Loa Kulu merupakan daerah penghasil batu bara yang cukup tinggi. Hal ini dapat dilihat dengan adanya 3 perusahaan besar yang terletak di pinggir jalan raya Samarinda-Tenggarong yaitu lebih tepatnya di daerah Berhala, Pongkor, dan Merangan. Disamping memiliki potensi cadangan batubara yang cukup besar di sebagian wilayahnya, Kecamatan Loa Kulu juga dikembangkan sebagai salah satu sentra produksi pertanian dan perkebunan utama di Kabupaten Kutai Kartanegara yang ditandai dengan pembukaan lahan untuk persawahan dan perkebunan kelapa sawit. Dilihat dari sektor perekonomian, pembukaan lahan pertambangan dan pertanian memiliki dampak yang sangat baik bagi masyarakat khususnya kecamatan Loa Kulu tetapi sebaliknya dari segi ekosistem alam perluasan lahan untuk pertambangan dan pertanian dapat merusak habitat asli flora dan fauna endemik asli Kalimantan Timur. Pembebasan lahan yang berlebihan memiliki dampak yang sangat buruk bagi keberlangsungan ekosistem flora dan fauna khususnya di kecataman Loa Kulu Kabupaten Kutai Kartanegara. Ekosistem flora dan fauna di Kecamatan Loa Kulu menjadi terancam keberlangsungan hidupnya. Salah satu hewan/fauna yang terancam adalah kura-kura kaki gajah (manouria emys), dimana habitat aslinya berada di daratan pedalaman hutan.

Kura-kura kaki gajah atau dalam bahasa latin manouria emys merupakan kura-kura darat terbesar dikawasan Asia Selatan yang persebaran habitat nya di kawasan pulau di Indoensia seperti Sumatra dan Kalimantan. Kura-kura kaki gajah ini masuk kedalam suku testudinidae, dimana dalam bahasa inggris dikenal dengan nama giant brown tortoise, asian brown tortoise, atau asian forest tortoise. Fakta dilapangan menyatakan di habitat alamnya kura-kura jenis ini mulai jarang untuk ditemukan, terutama dikawasan hutan Kalimantan yang menjadi teritori atau wilayah kura-kura kaki gajah tersebut. Elden menjelaskan bahwa "Teritori atau wilayah, yaitu ruang yang tercipta secara sosial, dengan karakter yang terbentuk dari sejarah, budaya, dan asal muasal secara teknis dan politik ekonomi" (Elden, 2010). Sedangkan Vandergest menjelaskan bahwa "teritorialisasi adalah sebuah proses yang mana sebuah negara berusaha mengontrol orang-orang dan kegiatan mereka, dengan menggambarkan suatu batasan disekeliling ruang geografis, termasuk kategori individu dari ruang ini dan menetapkan atau melarang aktivitas tertentu di dalam batasan tersebut" (Vandergeest, 1996). Jadi wilayah atau teritori kura-kura kaki gajah harus menjadi pusat penangan

Informasi terakhir yang mencatat tentang keberadaan kura-kura ini adalah IUCN selaku lembaga internasional yang menangani konservasi alam dan sumberdaya global, 


\section{Jurnal Abdimas Mahakam}

https://journal.uwgm.ac.id/index.php/abdimasmahakam

Online ISSN : 2549-5755

Juni 2018, Vol.2 No. 2

menyatakan bahwa populasi kura-kura kaki gajah di alam adalah berstatus terancam kepunahan (Endangered, EN). Vand Djik menjelaskan bahwa "China merupakan salah satu negara yang menjadi konsumen kura-kura terbesar didunia. Komoditas perdagangan kura-kura yang ada di kawasan Asia sendiri telah lebih dari 13. 000 ton kura-kura" (Vand Djik et al. , 2000). Oleh karena itu sosialisasi konservasi terhadap kura-kura kaki gajah (manouria emys) sangat menarik diberikan bagi penangkar atau penghobi kura-kura kaki gajah (manouria emys) di Kecamatan Loa Kulu Kabupaten Kutai Kartanegara.

Di Kecamatan Loa Kulu, ada seorang penangkar kura-kura kaki gajah (manouria emys), yaitu Bapak Kautsar Eka Wardhana yang telah memelihara kura-kura kaki gajah sejak tahun 2016 dan memiliki 8 ekor kura-kura kaki gajah. Pada tahun 2016 sampai dengan 2018, aktivitas memelihara yang dilakukan Bapak Kautsar masih menggunakan dana mandiri. Kecintaannya terhadap kura-kura tersebut karena bentuk dan warna yang menarik dari kura-kura tersebut. Banyaknya informasi tentang pembakaran hutan, penebangan pohon, penambangan serta kura-kura kaki gajah yang dijadikan bahan konsumsi bagi manusia menggerakkan hati bapak kautsar untuk melestarikan atau mengembangbiakkan kura-kura kaki gajah. Selain itu, ada beberapa masalah yang dihadapi Bapak Kautsar yaitu lahan dan dana yang terbatas dalam mengembangbiakkan kura-kura kaki gajah (manouria emys) serta langkah-langkah konservasi terkait dinas yng bersangkutan.

Pelaksanaan kegiatan pengabdian ini diharapkan akan memberikan wawasan atau pengetahuan kepada masyarakat tentang konservasi/penyelamatan kura-kura kaki gajah dengan memberikan informasi tentang pemeliharaan serta sosialisasi penangkaran sebagai wujud dari konservasi penyelamatan kura-kura kaki gajah atau manouria emys di Kalimantan. Harapannya dengan semua kegiatan pengabdian ini akan tumbuh kesadaran tentang konservasi kura-kura kaki gajah (manouria emys) bagi masyarakat dan penangkar di Kecamatan Loa Kulu dan Anggana Kabupaten Kutai Kartanegara.

\section{Metode}

Dalam pelaksanaan program sosialisasi konservasi ini, tim pengabdian telah melakukan penyusunan rencana metode yang akan dilakukan selama proses awal sosialisasi dan rencana selama kegiatan berlangsung. Adapun dalam sosialisasi awal, tim pengabdian terlebih dahulu mengundang penangkar dan masyarakat Desa Loa Kulu Kota untuk mensosialisasikan kegiatan yang akan dilangsungkan. Dalam sosialisasi awal, tim pengabdian memiliki tujuan agar terjadi komunikasi timbal balik tentang bagaimana cara yang efektif untuk mengajak penangkar kura-kura kaki gajah oleh Bapak Kautsar Eka Wardhana dan Bapak Whendhy Bakti yang tinggal di Desa Loa Kulu Kota dan Anggana serta masyarakat desa Loa Kulu Kota untuk dapat ikut serta dalam kegiatan ini serta untuk mengetahui karakteristik para masyarakat di desa tersebut. Berikut akan disajikan tabel metodologi pelaksanaan kegiatan.

\begin{tabular}{c|l|c|c|c}
\hline No & \multicolumn{1}{|c|}{ Materi } & Metode & Evaluasi & Alokasi Waktu \\
\hline 1. & $\begin{array}{l}\text { Sosialisasi konservasi kura-kura } \\
\text { kaki gajah }\end{array}$ & Ceramah & Tanya jawab & $1 \times 60$ menit \\
\hline
\end{tabular}

Tabel 1. Metodologi Pelaksanaan Kegiatan

Pelaksanaan sosialisasi mengenai konservasi kura-kura kaki gajah dilaksanakan pada bulan Maret 2018, dengan menggunakan beberapa alat dan bahan yaitu: 1. Tenda; 2. Meja; 3. Kursi; 4. Baner/spanduk; 5. Mix; 6. Alat bantu simulasi berupa gambar kura-kura dan 


\section{Jurnal Abdimas Mahakam}

https://journal.uwgm.ac.id/index.php/abdimasmahakam

Online ISSN : 2549-5755

Juni 2018, Vol.2 No. 2

video langkah-langkah konservasi. Kegiatan penyampaian materi tentang sosialisasi konservasi dilakukan dengan beberapa cara sebagai berikut: 1. Ceramah, yaitu digunakan untuk memaparkan materi tentang langkah-langkah konservasi kura-kura kaki gajah, kondisi hutan di Desa Loa Kulu Kota, cara perawatan kura-kura kaki gajah, serta cara membuat data perkembangan kura-kura kaki gajah; 2. Tanya jawab, yaitu digunakan untuk merespon sejauh mana tingkat pemahaman peserta sosialisasi terhadap materi yang telah disampaikan; 3. Simulasi yaitu digunakan untuk memperlihatkan atau memberikan contoh nyata mengenai cara konservasi.

Adapun rencana rancangan evaluasi kegiatan pengabdian yang akan dilakukan, sebagai berikut:

1. Pelaksana evaluasi (evaluasi dilakukan oleh pengelola sendiri atau bersama pelaksana pengabdian dan oleh instansi berwenang);

2. Waktu pelaksanaan (evaluasi dilaksanakan pada bulan April sampai dengan Juni 2018);

3. Unsur evaluasi (prosentase tumbuh dan kesehatan kura-kura kaki gajah, penyedian asupan makanan, dan metode atau cara pelaksanaan. Berikut akan disajikan tabel unsur evaluasi:

\begin{tabular}{c|c|l|l|l|c|c}
\hline No & $\begin{array}{c}\text { Kode } \\
\text { Kura-kura }\end{array}$ & Berat & Panjang & $\begin{array}{c}\text { Kelengkapan } \\
\text { Bagian Tubuh }\end{array}$ & $\begin{array}{c}\text { Kondisi } \\
\text { Kesehatan }\end{array}$ & $\begin{array}{c}\text { Asupan } \\
\text { Makanan }\end{array}$ \\
\hline 1 & & & & & & \\
\hline 2 & & & & & & \\
\hline 3 & & & & & & \\
\hline 4 & & & & & & \\
\hline $\mathrm{dst}$ & & & & & & \\
\hline
\end{tabular}

Tabel 2. Unsur Evaluasi

4. Cara evaluasi (cara evaluasi dilakukan dengan cara sebagai berikut: a. pemberian kode pada kura-kura kaki gajah yang berada di penangkaran; b. mengukur berat dan panjang kura-kura kaki gajah yang disesuaikan dengan kode kura-kura kaki gajah; c. pengecekan kesehatan/kondisi kura-kura kaki gajah (kelengkapan bagian tubuh/diagnosa penyakit jika terjadi serangan bakteri, virus serta gangguan pada kurakura kaki gajah); d. pembuatan jadwal pemberian makanan dalam sehari dengan jumlah asupan yang disesuaikan. e. data dan informasi tentang kondisi kura-kura kaki gajah di laporkan dengan instansi terkait.

5. Hasil evaluasi (membuat dan menyampaikan laporan yang memuat kemajuan kondisi fisik kura-kura kaki gajah).

\section{Hasil dan Pembahasan}

Kegiatan pengabdian kepada masyarakat dilaksanakan dalam rangka perijinan dan pendampingan terkait konservasi kura-kura kaki gajah. Adapun hasil dari kegiatan sosialisasi konservasi kura-kura kaki gajah sebagai berikut:

Pertama, hasil kegiatan sosialisasi di Dinas Perikanan dan Peternakan Kota Samarinda yaitu proses pelaksanaan konservasi penangkaran kura-kura kaki gajah ini sekarang bukan menjadi prioritas penanganan dari Dinas Perikanan dan Peternakan. Fokus Dinas Perikanan dan Peternakan sekarang ini menangani dalam hal yang menyangkut periikanan, amphibi maupun reptile namun yang sifatnya non appendix, atau bukan satwa yang dilindungi Undang-Undang Indonesia, sehingga Dinas Perikanan dan Peternakan 


\section{Jurnal Abdimas Mahakam}

https://journal.uwgm.ac.id/index.php/abdimasmahakam

Online ISSN : 2549-5755

Juni 2018, Vol.2 No. 2

mengarahkan pengabdian ini langsung kepada BKSDA KALTIM yang berada di Samarinda. Hal ini dilakukan dengan alasan, bahwasannya untuk konservasi satwa yang dilundungi atau yang masuk kedalam daftar Appendix IUCN menjadi wewenang dari BKSDA KALTIM itu sendiri.

Kedua, hasil kegiatan sosialisasi di BKSDA Kaltim sebagai berikut: 1. Untuk pengabdian sosialisasi konservasi ini BKSDA KALTIM memberikan saran berupa informasi, bahwasannya syarat yang harus dilakukan yaitu harus ada kuota penangkar guna memenuhi kuota konservasi yang mana kuota penangkar harus sesuai standar dan tercatat didalam dokumen BKSDA KALTIM sebagai dasar kegiatan konservasi; 2. Hewan ini (kura-kura kaki gajah) masuk kedalam daftar hewan yang dilindungi atau belum, walaupun pada dasarnya manouria emys sudah masuk kedalam catatan IUCN appendix II yang kedepannya terancam kepunahan. Namun dalam catatan BKSDA KALTIM sendiri belum ada yang berfokus konservasi kura-kura tersebut; 3. Untuk kegiatan kedepan, jika sudah berjalan konservasi haruslah jelas berapa persen yang dilepas liarkan dan berapa persen yang dikomersilkan secara legal harus seimbang; 4. Tempat konservasi pelepasan kura-kura kaki gajah juga harus ditentukan terkait habitat aslinya dialam yang masih terjaga. Saran yang diberikan pihak BKSDA KALTIM dan Penangkar yaitu di daerah Kutai Barat; 5. Sosialisasi ini dilaksanakan secara bertahap dan kontinu jadi harus berkelanjutan sehingga proses konservasi dapat terbangun; 6. Saran dari BKSDA KALTIM andai penangkar berkeinginan mau mengambil kuota peternak yang ada di pulau Jawa bisa dan diijinkan, akan tetapi tidak dapat dijadikan konservasi hanya sebatas komersil, mengingat itu kura-kura kaki gajah Sumatera/emys sumatera.

Ketiga, hasil kegiatan sosialisasi di WWF (World Wildlife Fund) adalah: 1. Disarankan langsung mengajukan surat dan TOR/ agenda sosialisasi kepada kepala BKSDA KALTIM terkait sosialisasi ini; 2. Untuk pencarian perijinan legal formal penangkaran berbasis konservasi di keep lebih dahulu dan dijadikan penelitian jangka panjang yang berkelanjutan; 3. Untuk pengabdian ini disarankan untuk dijadikan riset yang berkelanjutan, karena termasuk dalam riset dengan tema yang menarik dan belum ada kelompok maupun perorangan yang konsen dalam konservasi manouria emys; 4. Untuk sesi pengabdian lanjutan pihak WWF bersedia turun langsung dalam memberikan edukasi yang sifatnya lebih menjaga habitat si kura-kura tersebut yang estimasi waktunya dibulan Juli setelah Idul Fitri; 5. Untuk konservasi dan penangkaran bisa lebih dititik beratkan ke pihak BKSDA KALTIM, karena mereka yang punya hak dan wewenang secara resmi dalam melegalkan konservasi tersebut. WWF hanya bisa memberikan edukasi terkait penyelamatan manouria emys sesuai tupoksi dari WWF itu sendiri.

Keempat, hasil kegiatan sosialisasi di gathering dengan komunitas kura-kura manyara mahakam sebagai berikut: 1. Para penangkar kura-kura kaki gajah mengharapkan ada bantuan dari dinas terkait seperti BKSDA untuk mendampingi mereka dalam menjalankan upaya penangkaran kura-kura kaki gajah ini; 2. Adanya perijinan legal dari BKSDA bagi para penangkar kura-kura di wilayah Kalimatan Timur khususnya sehingga mereka bisa legal menjalankan proses pemeliharaan dan penangkaran kura-kura kaki gajah tersebut; 3 . Mendapatkan ijin resmi penjualan kura-kura kaki gajah khususnya dengan ijin resmi dari dinas terkait seperti BKSDA, hal ini disampaikan bahwasannya selain menangkarkan dengan melepaskan beberapa persen hasil anakan kura-kura kaki gajah, penangkar juga mendapatkan ijin resmi penjualan kura-kura tersebut secara legal; 4. Pembuatan Tim oleh para anggota komunitas kura-kura manyara mahakan sebagai wadah resmi guna 


\section{Jurnal Abdimas Mahakam}

https://journal.uwgm.ac.id/index.php/abdimasmahakam

Online ISSN : 2549-5755

Juni 2018, Vol.2 No. 2

mengajukan kuota penangkar kepada BKSDA sebagai persyaratan dari konservasi kurakura kaki gajah; 5. Sharing tentang kendala dan kiat dalam penangkaran kura-kura khususnya kura-kura kaki gajah yang menjadi konsen dari pengabdian masyarakat ini; 6 . Penangkar bersedia menjadi mitra dan menjalankan pengabdian secara bertahap dan kontinu demi keberhasilan pelaksanaan konservasi kura-kura kaki gajah; 7. Pendataan kura-kura kaki gajah yang dimiliki oleh para anggota yang nantinya menjadi basic data yang digunakan sebagai laporan pengabdian masyarakat.

\section{Simpulan}

Pelaksanaan pengabdian masyarakat melalui sosialisasi konservasi kura-kura kaki gajah telah dilaksanakan sesuai dengan target dan tujuan yang direncanakan. Respon yang diberikan penangkar yang juga masyarakat menyambut positif pelaksanaan pengabdian ini. Adapun pihak pemerintah sebagai pendampingan pengabdian masyarakat yakni BKSDA KALTIM dan WWF cabang Samarinda dari pihak LSM Swasta juga memberikan dukungan dan saran bagi pelaksanaan kegiatan pengabdian ini.

Pelaksanaan pengabdian ini disarankan untuk dijadikan riset yang berkelanjutan, mengingat pengabdian ini termasuk dalam riset dengan tema yang menarik dan belum ada kelompok maupun perorangan yang konsen dalam konservasi manouria emys. Pihak BKSDA selaku lembaga resmi pemerintah dalam menangani dibidang konservasi diharapkan lebih berperan dalam melakukan sosialisasi terhadap hewan kategori reptile khususnya kura-kura. Sehingga keberlangsungan kura-kura dapat terjaga baik populasi maupun ekosistemnya. Kurangnya penyuluhan konservasi kepada masyarakat menyebabkan terjadinya perusakan ekosistem dan penangkapan liar terhadap kura-kura khususnya kura-kura kaki gajah.

Melalui pengabdian ini pihak penangkar kura-kura dapat terbantu dalam mencari ijin legal penangkaran kura-kura sekaligus menjadi jembatan untuk melestarikan kura-kura. Pihak-pihak pendamping pengabdian masyarakat yaitu, WWF dan BKSDA diharapkan dapat bekerjasama dalam menjaga kura-kura dari kepunahan. 


\section{Jurnal Abdimas Mahakam}

https://journal.uwgm.ac.id/index.php/abdimasmahakam

Online ISSN : 2549-5755

Juni 2018, Vol.2 No. 2

\section{Daftar Pustaka}

Elden Wiebe, Mills, \& Albert J. Gabrielle Eurepos. (2010). Encyclopedia of Case Study Research. California: Sage Publications Inc.

Van Dijk PP, Stuart BL, Rhodin AGJ. (2000). Asian turtle trade : proceedings of a workshop on conservation and trade of freshwater turtles and tortoises in Asia. Lunenburg, MA Chelonian Research Foundation. Chelonian Research Monographs No. 2, 164 pp. Dikutip dari Jurnal Penelitian Hutan dan Konservasi Alam Vol. 13 No. 2, Desember 2016: 119-135> pada 1 Januari 2018.

Vandergeest, Peter. (1996). Property rights in protected areas: obstacles to community involvement as a solution in Thailand. Jurnal: Environmental Conservation 23 (03), 259-268 